\title{
Studies on Development Status and Prospects of Chinese Language and Literature
}

\author{
Lei PEI \\ Chengde Radio \& TV University \\ Chengde ,067000, China
}

\author{
Shuli ZHOU \\ Chengde Radio \& TV University \\ Chengde ,067000, China
}

\begin{abstract}
Chinese Language and Literature aims to train specialized personnel for Chinese language learning community. The nature of its subject have significant differences with respect to the science and engineering professions which have relatively strong applications, therefore, Chinese Language and Literature in the community reflected that the applicability is not very obvious. Modern society proposed new requirements for high-qualified personnel, and determine the Chinese language and literature should enhance its applicability as soon as possible, so as to meet the needs of social development. This paper analyzes the basic characteristics of Chinese Language and Literature's education, and combine its development status and social reality requires of talents, also made thinking about issues that how to reform the constitution of Chinese Language and Literature Discipline exactly, in order to improve their teaching professionals.
\end{abstract}

Keywords- Chinese Language and Literature; Development Status; prospects

\section{INTRODUCTION}

A. has a long history, its teaching content are more fixed

As mentioned above, as the originator of modern higher education, China's Peking University set up a school in the literature as early as the beginning. This profession has gone through a hundred years of development. Teaching content and its teaching methods have been fixed. The requirements of the professional literature courses barely changed, according to "University undergraduate catalog" that issued in 1998 and the "Chinese colleges and universities undergraduate setting bible" in 2003 by the Ministry of Education. The number has been thirteen basic courses. All educators agree that the literary is the most professional disciplines among all traditional professions, and the most stable profession in the modern university system, and the discipline own its unique charm and rich content.

\section{B. Chinese language and literature will train professional} literary talents as the main objective

Over the years, Chinese language and literature as well as its predecessor, the literature has become the training base of writers and literary intellectuals. But from a sociological point of significance, these occupations are not the type to become community career, there is not much play features of its applicability. After the eighties of the last century, many schools of higher education created the Chinese professional in secretarial science, Journalism, International Chinese and other related professionals, the creation of these courses are designed to enhance the social applications resistance of Chinese language and literature, for the needs of social development application delivery related professional talents. But on the point of view of the nearest years, the employment situation of language and literature is not optimistic, the employment rate continued to decline, from this point, you can see the social application of this profession is not strong, the degree of social acceptance is not high.

\section{Less practical content in Chinese language and literature's education}

Chinese language and literature's education focus on analyzing the proficiency level of the students as well as Chinese language, students focus on literary quality, but relatively speaking and less on practical teaching content, and are generally concentrated in literary writing. Seeing from the teaching content, it is based on evidence that the practical application of the subject is poor.

\section{CURRENT PROBLEMS OF CHINESE LANGUAGE AND LITERATURE TEACHING}

There are problems in curriculum issues, compared with General Course class, specialized course in class was not enough, so that the depth in that profession is not enough; and the form of lectures, fewer hours of practical classes, the shortage of students vocational skills. Assessment system and forms are not standardized, some students' depth of expertise is not enough, but it can successfully get credits and graduate, largely due to the defects and flaws of Chinese language and literature's curriculum and assessment system. For example, the test paper is to examine some of the existing conceptual knowledge, and this paper determine the course of the performance, which allows students to focus on the final exam only and thus ignore the whole process of teaching. Students do not love this profession, the identity is not strong, and the depth of understanding is not enough. Lacking the great mission of honor in cultural heritage and are in low cultural quality. 
III. BRIEF ANALYSIS ON THE APPLICATION OF CHINESE LANGUAGE AND LITERATURE AND IMPROVED ITS PRACTICAL SIGNIFICANCE

\section{A. Application of Chinese Language and Literature improve practical significance}

To my opinion, the Chinese language and literature applied to improve the practical significance is mainly reflected in the following aspects: first, to improve the application of Chinese language and literature subjects conform to the actual needs of social development. The development of modern society needs comprehensive highquality talents, and proficiency in language analysis $\mathrm{s}$ undoubtedly important part in the basic quality of talent, therefore, the application of the increase in Chinese Literature in line with the social development process for talent requirements; secondly, application of Chinese Language and Literature meet the nature of the quality education. Our implementation of quality education has been all over the country, and now is the critical period of the implementation of the quality teaching in college education. And the goal of the quality education is to cultivate highquality personnel, the overall development of students' comprehensive ability, to enhance their overall literacy, and to strengthen the application of Chinese Language and Literature, we should have the ability in transferring the theoretical knowledge to analyze and solve practical problems, so that learning language and literature has become a theoretical system role in promoting social development, which Education is in line with the demand for talent; Furthermore, the increase application of Chinese Language and Literature is the essence of the law of development disciplines. Chinese language and literature set the study on the main object as Chinese language, which based on the language itself has a strong sense of instrumental and will determine its own characteristics of the ease of use.

\section{B. Employment sense on the improvement of application of Chinese Language and Literature}

Employment is a factor in the era of market economy, professional training must be considered. How is the employment direction of Chinese Language and Literature? In general, this profession has a more extensive range of employment. As "China University Students Career" magazine proposed the teacher, various editing positions, secretarial and planning staff. This proposal is not just a theoretical setting, a survey has been done by Chinese Department of Zhejiang University confirmed the suggestion of reality. During the two decades after "Cultural Revolution", Zhejiang University, Chinese Language and Literature and Classical literature graduates, mostly focused on their career in government, education and scientific research, journalism, publishing, business and other units, and a small number of people involved lawyers, real estate, trade finance and other emerging industries. The graduates of Chinese Language and Literature of applied universities which are different from research universities, primarily to the market rather than integration into society and academic research studies, the market they face seems to be more big: primary and secondary school teachers, grassroots civil servants, community services and management, the company clerk, journalists, community organizations and cultural institutions of employees and so on. This shows the Chinese Language and Literature has a wide career adaptability, but it also shows that, after the secretary, news, advertising, public management, derived from the Chinese Department of career orientation distinctive professional independence, Chinese Language and Literature will face greater competition. After losing the distinctive positioning of career, is Chinese language and literature completely lose their advantage? It seems not absolutely. In each category of analysis about Chinese professional employment's strengths and weaknesses take by "China University Students Career" magazine, the Chinese language and literature is not only relatively secretary, Journalism Canton, advertising and other professional employment opportunities, and there is no evaluate like " low level professional" and "the quality is not high". That said, Chinese language and literature provides some spiritual heritage, and is unique to other professionals. Traditional enable students to develop not only the influence of the people, the basic view of the world and basic values in professional learning, but also expose a special conversation between temperament, a specific realm. If enable students to master the skills of a professional upon this basis, then there's no doubt that you can make students have a stronger competitive capacity.

So according to the "job" how to reflect the application of Chinese language and literature? I think, do not rigidly adhere to the language and literature itself, and also can combine the development and employment history of Chinese Language and Literature with its status quo for the cultivate of professional skills. Chinese language and literature as a traditional specialty, in its long-term development, and carries out a number of emerging professional, news, advertising, clerical, and even public administration are basically stripped from the womb of Chinese language and literature. There is ceaseless blood kinship between mother and its diversity, on the tree of Chinese language and literature, those branches separated still continues to grow. Therefore, to ensure a solid professional foundation premise, applications and careerrelated skills training module design seems to break the artificial setting of professional boundaries, so as to a play greater advantages of Chinese language and literature. Education and teaching, journalism and communication, secretarial and public relations, community and cultural management, advertising, etc., can be designed as the application modules of Chinese Language and Literature, students gain hands-on skills and professional capabilities by learning these modules. 


\section{THE DEVELOPMENT PATH THAT CHINESE LANGUAGE AND LITERATURE HAVE TO GO}

\section{A. Chinese language course structure adjustment}

The development of Chinese language and literature should keep up with the pace of era's development, according to the needs and requirements of the new era of social developments. We should cultivate the talents who have literary aesthetic ability, communicative competence and professional writing skills literary. In order to ensure the development of Chinese language and literature teaching we should change the law of education to change the traditional teaching methods, enrich classroom teaching content, and should target on the changes of syllabus and lesson plans, to highlight the advantages and importance of Chinese Language and Literature in the development, which also attracted students will resonate.

\section{B. change the traditional classroom teaching methods}

In traditional classrooms, teachers is the dominant, the whole class can only listen to the teacher's gushing speech in front of the podium. Instructor immersed in that section of the ancient and modern literature, but did not have any impact on students, sleeping appear everywhere in classroom. So if you want to ensure that the development of Chinese language and literature, to change the traditional teacher "mouthpiece" of teaching methods is essential. To enable students to express their views in the classroom, and can give full play to their imagination to explain the literature, teachers and students can communicate with each other, classmates can also discuss with each other. It not only the training of students' thinking ability, imagination, verbal ability, adaptability also affect the ability of students to the art of infection through the teaching model of students ask questions - enable students to analyze - independently discuss of students - let students to answer the question.

\section{C. adjustments of Chinese Language and Literature Teaching Content}

Now the propagation velocity of the Chinese language is very broad, more and more people learning the Chinese language. To make Chinese face to the world, applied to every corner of the world, adjust the teaching content is essential, applying new knowledge of history and values to make the interpretation of literary. The adjusted teaching content make the relevant literature, writing and language related to the Chinese language and literature courses emphasis in mutual contact. As for the personalized development requirements for contemporary personnel, should be targeted for its professional training in the teaching process, so you can ensure the development of Chinese Language and Literature under the new era.

\section{D. changing the concepts of education}

With the continuous development of modern society, the Chinese language and literature to be formed school characteristics must change the concept of education. We all understand the practical value that the key factors of things determining its development, many students are vague to the professional concepts of Chinese language and literature, mainly because the education idea of Chinese language and literature is not strong and the professional confusion. Therefore, in order to ensure the Chinese language and professional foothold in the community, we must combine the needs of times and social development to change, enhance the educational quality and form the school characteristics through the ability education to students, and strengthen aspects of education and training of students' interest, so that the Chinese language professional talents are more in line with the capacity requirements.

\section{E. training for the employment ability of Chinese language and literature personnel}

With the development of the country, the demand for people is also growing and deepening. Now many graduates of Chinese language unable to meet the professional of competence job, argues that the principles of information arrangements are: There are old and new points

of information; the old information exists before the new information; a single new message is limited. With the advance of the sentence, the former ingredients rather the later ingredients of linear order can provide more new information. As mentioned earlier, "lack of" object can be brought front, the verb "lack" at the end of the discourse, is a typical location of the new information with greater communication value. And can be used to emphasize, highlight the lack of justice.

\section{F. Chinese language and literature should attach importance to students' creative thinking}

Chinese language and literature is a professional that cover a broad range of knowledge and with a strong cultural identity, so that requires Chinese language majors should have a rich cultural heritage during the learning process. Requirements to Chinese Language and Literature teacher in the teaching process are that they should focus on the students building of innovative thinking. Teachers must first have the courage to blaze new trails in terms of ideology, and should have unique teaching methods and ideas. Teachers should stimulate students' awareness of thinking in the teaching process, so that students are getting used to thinking and like thinking. In the teaching process, they also initiate students to learn, encourage students' sense of discovery and to explore, allowing students to actively express their personal comments on specialized courses, have selfconfidence and learning motivation.

\section{CONCLUSIONS}

Chinese language has a long history in our country. Its influence is growing huge in the world, with the continuous improvement of China's comprehensive national strength, and also provides a vast space for the development of Chinese language. Chinese Language and Literature is a progressive professional, it was given a strong social vitality. If we want to spread the Chinese history and culture out to every corner of the world, we must continue to learn Chinese language and literature, exploration and change in practice. 


\section{References}

[1] Wang Xiaomei development issues of Chinese language and literature [J] group text world, 2012, 14: 78-79.

[2] Meng $\mathrm{Li}$ take the machine of the northern Gulf to promote private institutions of higher learning of Chinese Language and Literature Development - A Case Study in Guangxi Institute of International Studies [J] Modern Languages (Academic Comprehensive Edition), 2013 , 09: 157-160.

[3] Tan Dexi Confucian Classics of Chinese language and literature professionals to develop new models of thinking and practicing [J] Chinese university teaching, 2013,12: 39-40 + 46 .
[4] Zhang Yuping the exploration of the Chinese Language and Literature Training Mode [J] Huazhong Normal University (Humanities and Social Sciences), 2014, S4:93-96.

[5] Wang Fang of Chinese Language and Literature Development [J] young writer, 2012, 27: $147+149$

[6] Zhang Aiming, Zong Rui improvement of Chinese language and literature and analysis of application issues [J] Popular Literature, 2011, 08: 234-235. 